Марија Горо́́ева Димова

marija.gorgieva@gmail.com

\title{
Интердискурзивни варијации: односот книжевност - теорија
}

\begin{abstract}
. Ѓорѓиева Димова Марија, Интердискурзивни варијации: односот книжевност - теорија (Interdiscursive variations: the literature - theory relation). „Poznańskie Studia Slawistyczne” 2. Poznań 2012. Adam Mickiewicz University Press, pp. 155-168. ISBN 978-83-232-2409-9. ISSN 2084-3011.

The subject of this paper is the theoretical fiction genre as a manifestation of interdiscursive relations between fiction and theory/criticism. Firstly, this paper offers a brief overview of the constitutive features of the theoretical fiction genre; and secondly, these features are interpretatively confirmed through the novel Papokot na svetot (Navel of the World) by the Macedonian writer, Venko Andonovski.
\end{abstract}

Keywords: interdiscursivity, novel, genre hybridization, fiction-theory

\begin{abstract}
Некои наративи се многу потеориски во однос на останатите, но тие мора да бидат теориски сами по себе и во себе, а не да бидат конструирани како теориски низ проиесот на читање.
\end{abstract}

Марк Кари

Актуелните тенденции на кооперативно, комплементарно и симултано координирање меѓу одделните дисциплини, дискурси, уметности, медиуми, што добива свое терминолошко покритие во категориите интердисциплинарност, интердискурзивност, интермедијалност, интерсемиотичност се потврдува и низ сѐ поинтензивниот дијалог што се воспоставува помеѓу книжевноуметничката практика и теоријата (главно, книжевната, но не само таа). Иако не станува збор за нов феномен, сепак, во актуелниот миг односот книжевност - теорија е издигнат на рамниште на поетичка доминанта и, свесно и функционално, е контекстуализиран во пошироките процеси на про- 
блематизирање на границите - било жанровски, било дисциплинарни. При тоа, проблематизацијата на традиционално сфатените релации меѓу книжевноуметничката практика и теоријата, којашто структурно е интериоризирана во рамки на книжевните текстови, добива и теориско промислување под одредницата теоретска фикција. Промоторот на оваа жанровска кованица е британскиот теоретичар Марк Кари, којшто упатува на потребата од поимско покривање и теориско промислување на една особено интензивна тенденција во книжевната продукција - тенденцијата да се трансгресираат границите меѓу фикцијата и теоријата/критиката, односно меѓу книжевноста и науката ${ }^{1}$. Со оглед на тоа што дефинирањето на теоретската фикција Кари го ситуира врз позадината на постојните теории за метафикцијата, во поширока смисла, теоретската фикција може да се посматра и како варијанта на метафикционалните жанрови.

Имено, поимањето на метафикцијата како свест за сопствениот идентитет како фикција ${ }^{2}$ го имплицира присуството на теориските аспекти во рамките на овој жанр. Токму Марк Кари, типолошки, ги фокусира начините на интериоризирање на теориските елементи во метафикцијата, кога говори за метафикцијата како граничен дискурс, којшто е свесен за сопствениот статус како лингвистички конструкт, како хибрид меѓу книжевноста и теоријата. Меѓутоа, Кари поаѓа од проблематизирањето на поимот самосвест врз којшто се темелат постојните дефиниции на метафикцијата: како фикција за себе самата

\footnotetext{
${ }^{1}$ Паралелно со тенденциите за очигледна теоретизација на фикцијата, може да се проследат и тенденциите за литераризација, коишто се преферираат во рамки на теоријата на книжевноста.

2 Теориските аспекти на метафикцијата ќе бидат посочени и од страна на Патриша Во, којашто констатира дека „метафикционалните романи ја истражуваат теоријата на фикцијата низ практиката на пишување фикција”, односно дека актуелноста на овој облик се врзува за генералната инклинација меѓу писателите да артикулираат повисок степен на свест за „теориските прашања кои се вовлечени во конструирањето на романите". P. Waugh, Metafiction. The Theory and Practice of SelfConscious Fiction, London-New York 1996, str. 2. Конечно, теориските аспекти се сугерирани и од страна на Линда Хачион, чијашто дефиниција ја потенцира коментаторската позиција на метафикцијата по однос на сопствените наративни и/или лингвистички идентитети. L. Hutcheon, Narcissistic Narrative. The Metafictional Paradox, New York-London 1984, str. 1.
} 
(дефиниции кои се актуелни во доцните 60-те години), односно како фикција што содржи самосвест, самознаење, ирониска самодистанца (дефиниции од 70-те години). Основниот проблем околу самосвеста како дефинирачки поим, тој ја лоцира во неговата недоволност и несоодветност. Имено, дефинирањето на метафикцијата како самосвесно пишување индицира вид пишување кое наполно е интровертирано и секогаш свесно (само) за себе како фикција. Но, според Кари, самосвеста е недоволна одредница затоа што упатува на присутната свест за себе како фикција, но не и како метафикција. Метафикцијата претпоставува (само)свест и за својата самосвест што, практично, сведочи за една бескрајна логичка регресивност на поимот самосвест. „Ако метафикционалното пишување е свесно за својата природа како фикција, тоа не е доволно за да се знае дека фикцијата мора да биде исто така свесна и за своето постоење како метафикција. Оттаму и прашањето дали воопшто е значајно да се каже дека метафикцијата е свест за себеси?"”. Вториот аргумент за несоодветноста на поимот самосвест како дефинирачки параметар Кари го пронаоѓa во фактот што „постмодернистичките романи кои рефлектираат врз себе, всушност, се коментатори и на своите претходници", така што самосвеста не значи единствено свест за сопствената фикционалност, туку и свест за останатите претходници во сопствената историја. Несомнено, сугерирајќи ја можноста од вакво проширување на концептот, Кари го вклучува и метатекстуалниот аспект ${ }^{5}$ во метафикцијата. Конечно, меѓу причините за терминолошката непрецизност се наведува и пукнатината што се отвора помеѓу релативно новиот термин и постоечките книжевни одлики што ги опишува тој: конфузијата што произлегува од односот меѓ критичкиот термин

\footnotetext{
${ }^{3}$ Metafiction, ed. M. Currie, London-New York 1995, str. 1.

${ }^{4}$ Ibidem.

${ }^{5}$ Во случајов, го имаме предвид дефинирањето на метатекстуалноста како еден од типовите транстекстуалност за коишто говори Жерар Женет, а кој ја опфаќа релацијата коментар - коментиран текст: „Единство на еден текст со друг текст за којшто тој говори без нужно да го цитира или да го повикува, дури и без да го именува" Ж. Женет, Палимпсести, прев. К. Куулавкова, во: Теорија на интертекстуалноста, прир. К. К'улавкова, Скопје 2003, стр. 67.
} 
(метафикција) и неговиот книжевен објект (метафикционалните романи) се должи на фактот што книжевниот објект самиот „перформира критичка функција”. Но, токму оваа комплексност не е сигнализирана во дефиницијата за метафикцијата како фикционална самосвест. „Самоконтемплацијата, или рефлексивноста, е фундаментално критичка бидејќи таа нѐ упатува на други текстови, на наративноста, воопшто, но не од некоја олимпска позиција на метајазична дистанца, туку од внатре, од дискурсот на кој рефлектира"б.

Во намерата да понуди редефинирање на поимот, Кари се фокусира и врз една друга димензија на метафикцијата, врз книжевната самосвест која се создава на границата помеѓу книжевноста и критиката: фикционалниот текст ја вклучува и критичката саморефлексија која ја демонстрира текстуалната свест за сопствената артифициелност, додека границата меѓу книжевноста и критиката е означена како вид (само)коментар во книжевноста. „Метафикцијата е граничен дискурс, вид пишување кое се сместува себеси на границата меѓу фикцијата и критиката, кое ја зема границата како своја тема"7. Токму оваа граница е видена како точка на конвергенција каде што се реализира нивното заемно асимилирање од внатре, како и продуцирањето самосвесна енергија на двете страни, обезбедувајќи рамноправна профитабилност: за критиката тоа значи афирмација на литерарноста во рамки на сопствениот јазик, зголемена свест за степенот во кој критичките проникнувања се формулирани во рамки на книжевноста и тенденција кон иманентност на критичкиот пристап којшто ја доведува во прашање способноста на критичкиот јазик да реферира објективно и авторитативно кон книжевниот текст. За фикцијата, пак, тоа значи асимилација на критичката перспектива во рамки на фикционалниот наратив, свест за артифициелноста на сопствените конструкции и фокусираност врз односот помеѓу јазикот и светот.

Оттаму, за да ги сигнализира овие димензии во метафикцијата, односно дистанцирањето од самосвеста како дефинирачка одлика, Кари го преферира терминот теоретска фикција: како ознака за фикција која има теориска или критичка функција во однос кон себе и кон

\footnotetext{
${ }^{6}$ M. Currie, Postmodern Narrative Theory, New York 1998, str. 69.

${ }^{7}$ Metafiction, str. 2.
} 
сопствените конвенции ${ }^{8}$. Иако внесувањето критичка експертиза во романот не е единствениот начин на дисеминирање на теоријата, сепак, според Кари, тоа е актуелен начин на давање критичка функција на романот, способност да ја истражува ,логиката на наративот без да прибегнува кон метајазик”. Оттаму, и одредувањето на теоретската фикција и како вид „перформативна наратологија”: ослободена од дистанцираните метајазични описи по однос на објектот - наратив, таа ги перформира своите сфаќања за наративот додека самата е наратив. Во таа смисла, Кари го посочува и двојството романсиер критичар/теоретичар како еден облик на персонификација на границата помеѓу фикцијата и теоријата, макар што, биографскиот аспект, нужно, не е конститутивен за теориските фикции 9 .

Меѓу бројните можности на наратолошка перформативност коишто се понудени во рамки на теоретската фикција, спаѓаат и интертекстуалните постапки, сфатени како маргинален случај на теоретска фикција $^{10}$. Книжевната практика изобилува со примери на романескни артикулации на постструктуралистичките концепции на интертекстуалноста, коишто романите ги „перформираат” преку своите интертекстуални релации кон другите текстови (книжевни, историски, теориски), така што теоретските фикции го деривираат наратолошкото знаење за останатите текстови врз основа на сопствените интертекстуални перформанси, а не врз основа на метајазичните искази. Од друга страна, голем дел од теоретските фикции во фикцио-

8 Теоретската фикција може да се посматра и како една експликација на сфаќањето на Умберто Еко на двојното кодирање во постмодернистичкиот роман и, особено, онаа варијанта што тој ја именува како квалитетен бестселер. U. Есо, O književnosti, prev. M. Piletid, Beograd 2002, str. 200. Од друга страна, словенечкиот теоретичар Миран Хладник го користи терминот професорски роман, макар што со него покрива само еден аспект на теориската фикција на Кари. Меѓутоа, ниту Еко, ниту Хладник не реферираат на теоријата и на терминологијата на Марк Кари, така што овде изведуваме типолошки паралели.

${ }^{9}$ Кари ги има предвид реципрочните односи кои ја осведочуваат аспирацијата на критичарот да биде фикционален писател, односно аспирацијата на романсиерите да ги асимилираат критичките перспективи во наративен процес.

${ }^{10}$ Кари ја посматра интертекстуалноста како маригинален случај на теориска фикција, во смисол дека таа, имплицитно, го сугерира односот фикција - критика/теорија, односно, имплицитно, ја сугерира сопствената артифициелност. 
нална форма ги артикулираат и постструктуралистичките теории за историските наративи, односно историографските теории за фикционалните и за наративните димензии на историјата.

Романот Папокот на светот (2000) на македонскиот писател Венко Андоновски е парадигматичен по однос на оваа варијанта на теоретска фикција. Андоновски, и биографски и творечки, го носи во себе двојството за коешто говори Кари: од една страна, тој е афирмиран теоретичар и практичар на фикцијата (универзитетски професор, книжевен критичар/теоретичар и писател), а од друга страна, романот, експлицитно, го структурира според перформативно-наратолошкиот модел. Конкретно, овој жанровски модел е посредуван преку интертекстуалните постапки што се употребени во романот и преку нивните метатекстуални функции. Во генерална смисла, метатекстуалните коментари што постмодернистичката литература ги афирмира и на интертекстуално и на автореференцијално рамниште, ја конципираат оваа проза во знакот на теоретската фикција, односно фикција со критичка и/или теориска намера, чијашто цел е да го води романот до наратолошка територија, до истражување на теоријата на фикцијата преку пишувањето фикција. Станува збор за можноста автореферентните и хетерореферентните стратегии, т.е. интертекстуалните постапки, воопшто, да посредуваат во инсталирањето на теориско-критичките рефлексии во романот, кои ќ ја означат неговата наратолошка свест, меѓутоа не од вообичаената метајазична, критичка дистанца, туку од иманентно интертекстуално и метатекстуално рамниште.

На рамниште на интертекстуални постапки Папокот на светот е парадигматичен од аспект на примената на еден од најексплоатираните цитатни модели во постмодернистичката проза - вакантната цитатност. Во него цитатната релација е остварена преку т.н. вакантна (празна) цитатност, обележана со отсуство на односот на интертекстуална еквиваленција помеѓу цитатот и прототекстот. Псевдоцитатноста и парацитатноста се двата подвида вакантност, во зависност од тоа дали постои или не постои реален прототекст ${ }^{11}$. Во согласност со оваа типологија во романот на Андоновски ќе се идентификува псевдоцитатната варијанта, која се користи со техниката на пронајден ракопис, односно со „реконструкција на изгубена или на

\footnotetext{
${ }^{11}$ D. Oraić Tolić, Teorija citatnosti, Zagreb 1990, str. 18.
} 
непостоечка алка на текстот" како типично цитатен облик текст во текст, со експлицитно назначување и интегрално, ,автентично” вградување на туѓите, цитатно повикани прототекстови:

1) предговорот на приредувачот: овој паратекст е конципиран како лаички коментар на приредувачот, идентификуван низ псевдонимот Јас, инаку брат на псевдоавторот. Тој, уште на почетокот, предупредува на сопствената книжевна некомпетентност, со што, практично, се оградува од материјалот што го приредува:

Да расчистиме уште на почетокот (сметководител сум и сакам чисти сметки): ова издание го давам на увид и го издавам на свет само поради брат ми. Односно поради куферот - ковчеже на брат ми, што ми го врачија пет минути пред да ми го испорачаат телото во лимен сандак ... она што всушност пресуди да се решам на еден ваков безумен чекор - објавување на заоставнината на брат ми: стотина и триесет странички текст отчукан на машина, на полужолти листови, со наслов „Папокот на светот”, а под него, со мали букви: ,„роман”,13.

Но, дури и од таа нестручна позиција, приредувачот, сепак, го коментира ракописот на братот, допуштајќи си дури и ко-авторски интервенции во него: тој, постојано, го искажува своето сомневање околу оригиналноста на текстот и околу неговото авторство, аргументирајќи со повеќе причини: бидејќи не верува во книжевниот талент на брата си, бидејќи препознава сличности помеѓу текстот што го приредува и текстовите пронајдени во лектирата на покојникот (есеистички книги, научни студии, библиската Песна над песните), бидејќи се сомнева во можноста од добиена творечка помош од страна на познати автори, чии визит-карти ги пронаоѓ во заоставнината на братот (Горан Стефановски, Јордан Плевнеш, Соломон Маркус, Предраг Матвеевиќ). Сомневањето во жанровската припадност на текстот приредувачот го искажува во референциите коишто го квалификуваат ракописот како „роман”, како чудно издание, како роман-компилација. Од друга страна, редакторот интервенира и внатре во текстот што го приредува, иако не од авторско-креативни, туку од

\footnotetext{
${ }^{12}$ A. Popovič, Opozicija prototekst - metatekst, „Delo” br. 2, 1982, str. 29.

${ }^{13}$ В. Андоновски, Папокот на светот, Скопје 2001, стр. 5-6.
} 
приватно-дискрециони причини: имено, плашејќи се од јавното мнение на малоградската средина, тој ги заменува имињата на романескните ликови со имиња земени од Шега на Милан Кундера, единствената книга со која, како што тврди, не нашол сродности во романот на брат му.

2) приредениот ракопис, т.е. псевдо-романот Папокот на свеmom: постхумно објавена книжевна мистификација, составена од два дела: првиот, под наслов Клучалница, ја содржи повеста за Константин Филозоф, кој го дешифрирал натписот на Соломоновата чаша во Аја Софија во Константинопол; а вториот дел, насловен како Клуч, е дневникот на братот пишуван со полуесеистички дискурс.

3) судското сведочење на Луција Земанек, која е еден од ликовите во псевдо-романот, а нејзиниот „текст” цитатно е вметнат од страна на приредувачот.

4) поговорот-рецензија, повторно, во парацитатна улога, но овојпат како стручен осврт кон второто издание на псевдороманот, направен од доцентот по литература, д-р Венко Андоновски.

5) дополнение-коментар на приредувачот кон второто уметничко дело на неговиот брат - збирка љубовна поезија.

6) псевдо-стихозбирката Енигма: девет песни напишани од истиот авторот на псевдо-романот, чиешто авторство, повторно, е спорно. Самиот приредувач шпекулира со неколку можности - дека се работи за авторски текст на неговиот брат од средношколските денови, дека се работи за текст со прикриено авторство (вистинскиот автор е мајката на неговата сакана), или, пак, за компилација на творби од македонски поети (Анте Поповски, Петре Андреевски, Радован Павловски), што се констатира и во експертизата скицирана од страна на рецензентот.

7) приватно писмо до авторот на псевдозбирката со потпис на Б. Варошлија.

Цитататноста како доминантен и конститутивен принцип во структурирањето на Папокот на светот станува повеќекратно функционално, но секојпат во насока на демонстрирање на интертекстуалните, но и на пошироките постмодернистички концепции, вклучително, и во насока на демонстрирање на интердискурзивните трансгресии помеѓу фикцијата и теоријата. 
1. На рамниште на интертекстуална релација: во услови кога книжевната практика нуди бројни примери за „бескрајната уметничка, научна и животна цитатност" 14 романот на Андоновски илустрира една од хиперцитатните варијанти, низ коишто се демонстрира типичното постмодернистичко релативирање на границите во сите насоки: уметност-стварност, уметност-неуметност/псевдо-уметност. Во Папокот на светот тоа се реализира преку постапката на цитатно калемење и компилирање на хетерогените текстови, покажувајќи при тоа како еден псевдокнижевен текст (роман) и еден животен текст или текст од/за животот (дневник) може да се инсертираат во друг уметнички (кон)текст, да се најдат во непосредно соседство, да се прелеваат, во смисла да имаат идентична содржина, а нивните ликови идентична судбина, откривајќ и ја можноста едното да го препишува, да го содржи другото или да се огледува во и да се угледува на него, едниот да биде Клучалница, а другиот Клуч. Фактот што во структурата на романот се јукстапонирани и семантички се поврзани разнородни текстови - поетско-прозни (псевдо-уметнички текстови); писма, дневници, лаички коментари (неуметнички, приватни текстови); судски сведочења (административни текстови), рецензии (научни текстови), односно дека на исто рамниште егзистираат реални и измислени/лажни автори, сосема јасно ја експлицира постмодерната состојба на лежерно релативирање на границите и на нивелирање на световите. Таквата структура на романот наоѓa своја поткрепа и во тезата на Брајан Мекхејл за онтолошките доминанти на постмодернистичката проза и, во тој контекст, особено, со прашањето за импликациите од спротивставувањето и нарушувањето на границите помеѓу различните светови/текстови.

Во книжевноуметничкиот текст под наслов Папокот на светот од реалниот автор Венко Андоновски се интегрираат неколку експлицитни прототекстови - уметнички, псевдо-уметнички и транссемиотички, што резултира во мултиплицирана цитатна конструкција, од типот текст во текст во текст ... Цитирани се две книжевни мистификации: едната, псевдороманот Папокот на светот (кој не случајно има идентичен наслов како и реалниот уметнички текст на реалниот

\footnotetext{
${ }^{14}$ D. Oraić Tolić, op. cit., str. 210.
} 
автор), компилиран од различни уметнички, неуметнички и полууметнички текстови; другата е псевдостихозбирката Енигма, која, пак, е микстура на песни од македонски автори.

2. На рамниште на метатекстуална функција, која е во служба на илустрирање на постмодернистичката критичко-превреднувачка ориентација. Моделот на вакантна цитатност во Папокот на светот се открива во светлината на своевиден коментар за актуелните случувања во книжевно-уметничката и во книжевно-научната сфера, во смисла на критичко превреднување на параметрите што владеат и во творечката продукција и во нејзината критичка верификација.

3. И, конечно, цитатната интертекстуалност во Папокот на свеmот станува сигнификативна и на рамништето на коешто го експлицира моделот на „илустративната цитатност”, ката литература и нејзиниот однос кон минатото, воопшто, што се заговара во нејзини рамки. Во духот на постмодернистичките парадокси, романот на Андоновски ја свртува критичката острица и кон самиот феномен вакантна цитатност, кој застапува став за творечка продукција што ќe ја анулира и ќе ја игнорира традицијата како претекст или, пак, ќе реферира на неа од нихилистичко-негаторска позиција. Ваквата критичка димензија во Папокот на светот е илустрирана токму низ интертекстуалните процедури, кои ја допуштаат сеопштата поврзаност на различните текстовни остварувања и го сугерираат неминовното постоење на текстовни предлошки.

Структурирањето на Папокот на светот според моделот вакантна цитатност, несомнено, посредува и во неговото обликување според жанровските параметри на теоретската фикција. Во насока на перформирање на интертекстуално-метатекстуалните интенции на романот како носители на наратолошко знаење, односно на теориско-критичките рефлексии, во романот е индикативен токму двојниот коментар по однос на цитираната мистификација: еден некомпетентен коментар (предговорот на приредувачот) и еден компетентен коментар (поговорот на рецензентот), чиишто заклучоци наполно се идентични - тие искажуваат резервираност околу уметничката валидност на текстот. Но, на повисоко рамниште, оваа постапка има и мета-

\footnotetext{
${ }^{15}$ Ibidem, str. $43-51$.
} 
текстуална функција - таа е искористена како критика на одредени реални состојби во македонската книжевна средина, произлезени од „отсуството на учење по пат на макотрпна пистелска и теориско-стручна работа" ${ }^{\text {. }}$. Во романот интенционално е поставувањето на приредувачот и на неговиот лаички коментар, чијашто цел е да се евидентира не само појавата на давање стручни квалификации од страна на нестручни лица (критика на критиката или подобро речено на квази-критиката), туку и за да се евидентира степенот на деградираност на естетските вредности во уметничкото дело, во услови кога неговите уметнички недоследности се очигледни и низ семантичкото исчитување на текстот од страна на „наивниот” читател, или како што тоа е прикажано во романот, кога дури и сметководителите стануваат свесни за наратолошките пропусти. Вториот коментар, рецензијата на доцентот по литература, се состои во научна елаборација и аргументација на она што веќе беше констатирано од страна на приредувачот: бројни пропусти од наратолошка гледна точка, забелешки по однос на отсуство на елементарна логика во нарацијата - пропусти во проајретичкиот код (во логиката на нарацијата) и во семичкиот код (во логиката на структурирање на ликовите); непотребни ретардации, непотребна поучност поради оптовареност со параболи од христијанската догматика. Практично, ова рамниште во романот го обезбедува транспонирањето на теориските ефекти преку транспонирање на наративноста во нарацијата.

Рецензијата, паратекстуално интегрирана во романот, добива метатекстуална функција, што, секако е во склад со барањето на Ролан Барт: „Нека и самиот коментар биде текст”. Рецензентскиот осврт станува метакоментар на она ниво на коешто се разоткрива како апострофирање на оние чијашто стручна компетентност ја допушта хиперпродукцијата и квазипродукцијата. Тоа се потврдува и со фактот што доцентот по литература одлучил да го рецензира второто издание на романот, затоа што што се двоумел дали треба да прифати да расправа за дело кое апсолутно е сомнително, односно коешто се граничи со плагијаризам (критика на критиката по порачка):

\footnotetext{
${ }^{16}$ В. Андоновски, ор. cit., стр. 319.
} 
Точно е дека тој роман освои две крупни литературни награди, но моја должност, како на критичар-рецензент е да говорам отворено за делото, неоптоварен од признанијата. Јас дури искрено се чудам како критиката и луѓето во жиријата не ги виделе досега овие пропусти. Дали тоа, Ве молам, значи дека во оваа земја никој, освен доцентите по литература не чита книги и не се занимава со логика?! ${ }^{17}$.

Да заклучам (можеби е престрого, но на тоа ме обврзува не само моето белетристичко, туку пред се́ моето доцентско искуство, како и научниот идеал на објективен, систематски и исцрпен опис): станува збор за почетник кој, и покрај недостатоците, сепак ни понудил наместа интересно, читливо четиво ${ }^{18}$.

Ако на рамниште на книжевни постапки во Папокот на светот се проблематизира односот уметност-стварност, тогаш на рамниште на метатекстуална функција се проблематизира релацијата помеѓу автентичната уметност и псевдоуметноста, помеѓу оригиналот и копијата/плагијатот: „Судете вие-што и колку сѐ од ова е оригинално. И се разбира, колку вреди. Доколку, се разбира, оригиналноста е исто што и вредност!",

Несомнено, интертекстуално-цитатниот модел во Папокот на cветот може да се толкува како една реализација на теоретската фикција, потврдувајќи дека

идејата за критиката како интертекстуална, а не метајазична релација е она што ги обединува теоретските фикции на границата меѓу фикцијата и критиката. Интертекстуалноста поставува модел на референцијалност кој не може да дистингвира помеѓу референцата кон светот и референцијата кон другите текстови, додека текстуалноста е исткаена во сѐ̀ ${ }^{20}$.

Вака конципираната проза се пројавува и како илустрација на дел од тезите на Жерар Женет: прво, потврдува дека метатекстуалноста не е само право и привилегија на книжевната критика, туку дека таа може да се интериоризира и во рамките на уметничките текстови, кои ќе се објават како директен или индиректен коментар на другите

\footnotetext{
${ }^{17}$ Ibidem, стр. 321.

${ }^{18}$ Ibidem, стр. 322.

${ }^{19}$ Ibidem, стр. 329.

${ }^{20}$ M. Currie, Postmodern..., str. 70.
} 
текстови; и второ, ја демонстрира меѓусебната поврзаност на одделните транстекстуални типови, во случајов, помеѓу интертекстуалноста и метатекстуалноста и помеѓу паратекстуалноста и метатекстуалноста.

Конечно, романескните артикулации на интердискурзивните релации меѓу книжевноста и теоријата претставуваат уште еден начин на актуелизирање на оној жанровски квалитет и виталитет на романот што го констатира и Михаил Бахтин. Од една страна, интердискурзивните трансгресии меѓу фикцијата и теоријата може да се посматраат како варијанта на жанровските хибридизации, коишто ги откриваат капацитетите на романот ,да ги пародира другите жанрови (како жанрови), да ја разобличува условноста на нивните форми и јазици, едни жанрови да ги истиснува, а другите, преосмислувајќи ги и повторно акцентирајќи ги, да ги воведува во својата внатрешна конструкција" ${ }^{\text {"21 }}$ Оваа жанровска динамика, како иманенција на романот, ја манифестира неговата пластичност и неканоничност, неговата специфичност на жанр кој вечно трага, кој вечно се истражува себеси и кој ги преиспитува сите свои настанати облици. Од друга страна, експандирањето на еден фикционален жанр (романот) и во теориската, т.е. во наратолошката територија, може да се посматра и како израз на романескните тенденции за романсирање, идентификувано со секоја сила којашто се стреми да го сруши владејачкиот систем, којашто е динамична, којашто инсистира на постојан процес и на промена, во смисла на „ослободување од сето она што е замрено, неприродно, изживеано, безживотно, условно, што го кочи развојот и ги прави стилизации на преживеани форми" ${ }^{\text {,22 }}$.

\section{Литература}

Barthes R., Teorija o tekstu, „Republika” br. 9/10, 1986, str. 1098-1120.

Bahtin M., O romanu, prev. A. Badnjarević, Beograd 1989.

Eco U., O književnosti, prev. M. Piletid, Beograd 2002.

Hladnik M., Temeljni problemi historijskog romana, „Razlika/Différance” br. 1, 2001, str. 197-222.

\footnotetext{
${ }^{21}$ M. Bahtin, O romanu, prev. A. Badnjarević, Beograd 1989, str. 437.

${ }^{22}$ Ibidem.
} 
Hutcheon L., Narcissistic Narrative. The Metafictional Paradox, New York-London 1984.

McHale B., Postmodernist Fiction, London-New York 2001.

Metafiction, ed. M. Currie, London-New York 1995.

Oraić Tolić D., Teorija citatnosti, Zagreb 1990.

Popovič A., Opozicija prototekst - metatekst, „Delo” br. 2, 1982, str. 22-40.

Waugh P., Metafiction. The Theory and Practice of Self-Conscious Fiction, LondonNew York 1996.

Женет Ж., Палимпсести, прев. К. Куулавкова, во: Теорија на интертекстуалноста, прир. К. Ќулавкова, Скопје 2003, стр. 63-77. 